\title{
RETHINKING INNOVATION FOR DECARBONIZING ENERGY SYSTEMS
}

\begin{abstract}
While technological innovation is an implicit element of any plausible strategy for responding to climate change, the complexity of innovation processes has not been adequately accounted for in such strategies. Using many examples from different areas of technological innovation, we show that the inevitable unintended and unforeseeable consequences of innovation likely make it impossible to strategically steer the global energy system in desired directions. Given this conclusion, we then look at technological complexity in terms of a simple three-level schema of socio-technical change. This perspective points towards innovation policies that focus on long-term, incremental advance at the level of individual technologies, and on public policies that use a public goods-public works rationale to justify government investments in the needed innovations.
\end{abstract}

Keywords: innovation; climate change; public policy; energy systems. 
Technological innovation since the time of the first Industrial Revolution is the proximate cause of global warming. Further innovation in technical and social systems is the necessary route to mitigation. Always and everywhere, innovation is messy, complicated, and contingent. Major questions for mitigation of climate change begin with choice of policy tools for guiding the world energy system along desirable pathways. And while prospective technologies have been reasonably well mapped, policy choices_-dependent on political coalitions that solidify and dissolve unpredictably — cannot be similarly mapped. For example, governments must find ways to reduce emissions of greenhouse gases (GHGs) while at the same time providing ample supplies of low-cost energy for those who cannot afford high-cost energy, a difficult task in poor parts of the world and impoverished enclaves even in the wealthiest countries. They will have to devise political arrangements that foster innovation while dampening and diffusing opposition by interests that see their freedom of action and profits threatened.

With hindsight, the societal and technological aspects of innovation can be uncoupled; foresight necessarily remains conjectural because of system-level complexity. This essay explores the implications of such complexity for moving toward a low-carbon global energy system. Our argument unfolds in three parts. Sections 1, 2, and 3 examine the complexity of technological change in the contexts of energy, innovation itself, and the social forces that condition innovation. Section 4 provides a three-level framework for helping to make sense of the complexities explored in preceding sections. Section 5 discusses aspects of energy technology innovation that make it different from other technological domains, and Section 6 discusses why these differences make the shift away from carbon-based energy especially challenging. In our concluding section we articulate what we believe to be the two main lessons of our overall analysis. First, given the complexity and contingency of energy systems, steering them in a desired direction - that is, toward a zero-carbon future — can best be achieved through a focus on accelerating innovation of specific energy technologies. Second, and following from the previous point, policies aimed at accelerating a transition to a zero-carbon future will be most successful over the long-term when they adopt a direct, public goods approach to technological change.

\section{Introduction}


The essence of the climate-change dilemma for policy and politics has commonly been viewed in terms of externalities and the conflict between energy prices (actual, or shadow prices intended to offset externalities, in part or in whole, as for instance through carbon taxes) and presumptive climate change mitigation costs [1]. While narrowly true, the issues run deeper. In wealthy countries, economic, political, and cultural forces have locked in place systems (for electric power, for transportation) based predominately on fossil fuels [2]. These represent complex and often opaque political and social arrangements and enormous sunk costs. At the same time, fossil fuels remain relatively abundant and relatively inexpensive. No one can know what level of energy prices might be necessary to drive to completion, within a few decades, the social and technical changes necessary to move away from fossil fuels. More to our point, no one can know what highly unpredictable consequences for society and the environment such price rises might create.

The reasons reflect standard views of uncertainty in technological and sociotechnical systems. Short-term forecasting of many technological and some sociotechnical trends is feasible, and useful. Past some (unknowable) point in time, predictions, even for "simple" technological components and systems become increasingly likely to go off the rails [3]. For non-simple, that is to say complex systems [4] — uncertainty mounts because of incomplete or imperfect understanding of interactions among system components [5]. The usefulness and reliability of predictions therefore depends on context: on what is known, in terms of mechanism and past history, of the system in question, as well as on the time frame of interest.

In some cases, of course, prediction is impossible, as for scientific/technological discoveries without precedent in either theoretical understanding or past empirical findings. High-temperature superconductivity, an example that surfaces briefly later in this essay, illustrates. Three decades after the initial discovery in 1986, advances such as new material combinations resulting in higher critical temperatures still cannot be anticipated. This is because the well-established mechanisms that explain superconductivity in elemental metals and their alloys fail for the new classes of complex intermetallics synthesized since the mid-1980s and no adequate theory for these new materials has yet appeared. Research, under these circumstances, continues to be guided by heuristics. 
For existing technologies, or technological families, those for which an experience base exists to be queried-lithium-ion batteries for electrically-powered vehicles or flow batteries for grid storage - advances in performance (however performance might be measured) can be anticipated, within limits, through methods such as extrapolation of learning or experience curves. Absent a useful experience base, expert judgment easily goes astray. Zinc-air batteries, theoretically superior to lithium-ion cells, have been under development for decades; no one can say with confidence if or when rechargeable zinc-air batteries will become practical [6]. If they do, substantial changes in road vehicle technologies would likely follow, since zinc-air promises much greater range (because of much greater energy density) and much lower costs (since zinc is inexpensive) than lithium-ion systems. Given a few data points, learning curves for zinc-air systems and zinc-air-battery-powered electric vehicles would provide a basis for technological prediction.

Combining an innovation such as practical zinc-air battery systems with the socioeconomic dimensions of market acceptance, patterns of usage, and the ongoing evolution of transportation infrastructure and urban/regional development introduces complexity of the sort that defeats predictability. Indeed, even in hindsight explanations for outcomes involving social, political, and economic dynamics combined with technological development will sometimes remain contested more or less indefinitely, as for example in retrospective evaluations of choices made during the 1950s and 1960s among competing nuclear power reactor design concepts. Directions of technological change directly relevant to the climate-energy challenge may be powerfully influenced by unpredictable exogenous factors as diverse as political change (for example, US President Ronald Reagan's disinvestment in renewable energy in the 1980s), economic factors (for example the decline in hydrocarbon fuel prices due to improvement in hydrofracking techniques), or even geological events (for example, the 2011 Tohoku earthquake and tsunami and its effects on social attitudes toward nuclear power). Indeed, a major goal of this essay is to explore in a different way what uncertainties in technological change imply for successful policies aimed at decarbonizing energy systems.

\section{Innovation in Context}

Whatever pathways societies may follow in managing the consequences of GHG buildup,, those pathways are today unpredictable, and as they unfold are likely to be highly diverse. To 
begin with, invention, commercialization of innovations, and diffusion proceed differently in different parts of the world, depending on "innovation systems" that reflect institutional structures, politics, and culture, as well as technological particulars [7]. Nicholas Bloom, an economist who has conducted extensive cross-national comparisons of firm-level performance, may overstate, or maybe not, in saying "If Sam Walton had been based in Italy or in India, he would have five stores by now, probably called 'Sam Walton's Family Market.' Each one would have been managed by one of his sons or sons-in-law."8

More broadly, the common feature of innovation, whether technological, political, or behavioral (individual and societal), is this: Whatever is considered new is not just an idea but a change of some sort that has diffused and found acceptance, with observable consequences. In the pioneering analyses of Joseph Schumpeter during the first half of the $20^{\text {th }}$ century, which continue to underpin our understanding of innovation, business entrepreneurs devise and bring to market new products (automobiles, telephones), learn to produce familiar goods or services in new ways (catalog retailing in the 1920s, Internet retailing today), and introduce new forms of organization (joint stock corporations, lean production in manufacturing) [9]. All such efforts can also be understood as part of an ongoing process of social and technological co-evolution [10].

As Schumpeter understood, the immensely productive dynamism of economies such as that of the United States stems in large measure from the entry of new firms and the exit of old. New product concepts do not count as innovations until commercialization-marketplace introduction - after which some new products (and processes) survive and flourish while others fail, perhaps with the firms that introduced them. Studebaker built buggies, then automobiles, then disappeared, unable to defend the niche it occupied in a globalizing auto industry. As late as 1915, over 40 firms in the United States alone manufactured battery-electric automobiles, which then disappeared, to reemerge in the 1990s, only to vanish once more - and which now, finally, seem to have become established in a viable segment of the world market. In other illustrations, George Westinghouse made his fortune during the electrification of America early in the $20^{\text {th }}$ century, the company that bears his name went on to innovate in nuclear reactors for the Navy and then sold similar reactors to utilities, and Toshiba now owns the Westinghouse brand name. Pratt \& Whitney, but not Curtiss Wright, learned to design and manufacture jet engines in place of piston engines to meet the demands of military and civilian customers. Not surprisingly, as Schumpeter's influence grew, evolutionary analogies became common, with "the appearance, 
growth and disappearance of firms ... likened to the processes of birth, growth, and death of biological organisms" [11].

In views current today, the overall process reflects some combination of the forces of technology push, the result of inventors and entrepreneurs developing new goods and services in search of new and profitable markets, and market pull, the result of customers (individuals, households, businesses) seeking goods and services with attributes they value. Governments both push, as through R\&D programs, and exert pull, as through procurement. While governments buy goods and services of all sorts, purchases of new and emerging technologies for fulfillment of public missions have been especially powerful as drivers of innovation, a point that has long been clear to historians of economics and technology if not to always to students of innovation. Indeed, the high costs common for infant technologies may leave governments as the only customers initially. Companies in Britain and Germany built the first jet engines, purchased by governments for fighter planes during World War II. US military and space agencies paid for the first computers and navigation satellites, bought the first integrated circuit (IC) chips and solar photovoltaic (PV) cells, and after General Electric and Westinghouse developed nuclear propulsion reactors under contract for the US Navy's submarines, subsidized design and construction of the first commercial nuclear power plant in the United States (based on a Westinghouse design), at Shippingport, Pennsylvania.

Innovation pathways are tortuous. In the 1940s, to expand the jet engine example, these new power plants were far more costly to purchase and operate than piston engines; they were also unreliable and prodigious guzzlers of fuel [12]. No matter to militaries that adopted them, since jet fighters offered speeds and rates-of-climb far superior to propeller-drive planes, which could not hope to survive in aerial combat against them. Subsequent technical improvements came quickly and continued for decades. Defense agencies paid many of the bills, through contracts for procurement and for R\&D itself, and, less directly, through accumulation of operating experience, an aspect of innovation that economists call learning-by-using [13]. With evidence in hand of improvements in reliability and reductions in fuel consumption, airframe manufacturers began to design commercial aircraft around jet engines, and airline experience soon began making its own contributions to further technical gains. 
As learning-by-using in aviation suggests, along with many other cases, the sources of performance gains go beyond the narrowly technical. Nuclear power plants also performed poorly in their early years. Capacity factors - the fraction of power theoretically availableaveraged only 50-60 percent in utility service in the United States during the middle 1970s; by the early 2000s, the 100 or so plants then in operation were averaging 90 percent [14]. Nearly all these plants had been designed in the 1960s and 1970s, and most had been completed by the mid-1970s; their "technology," in other words, was largely fixed. Capacity factors rose as operators, technicians, engineers, and managers identified operating and maintenance practices that reduced the likelihood of unexpected outages and extended intervals between planned shutdowns. Only then did nuclear power become a reliable source of base-load generating capacity. These brief examples, and a great many other detailed accounts of innovation as it has occurred in different technological families and different industries, illustrate why long-term planning of broad fronts of technological advance is not possible.

Technical change can then be visualized in terms of sporadic, unpredictable bursts of moreor-less radical innovation that interrupt and sometimes alter long-term trajectories of performance improvement. The overall process has been called punctuated equilibrium, a further analogy drawn from evolutionary biology [15]. Evocative as it is, the label can mislead, since “equilibrium" cannot be taken literally. Ongoing innovations may themselves be quite fundamental, yet lose visibility as they become submerged in the long-term trend of improvement. Over time, gains of the sort represented by Moore's Law for ICs (not of course a natural law but simply an observed and self-fulfilling regularity) and the equivalent PV learning curve bring reductions in costs and prices, gains in functional performance, and expanding application ranges. Moore's Law itself reflects a great many quite fundamental technical advances, including whole new families of ICs, such as CMOS (complementary metal oxide semiconductor) chips - inexpensive to fabricate and low in power consumption, hence ideal for consumer products such as digital watches and hand calculators, their first big markets. Only the most detailed depictions of the Moore's Law trend reveal the consequent bumps and jerks.

Even though incremental innovation is ubiquitous, and central to technological advance, enthusiasts urging greater investments in radical and disruptive innovation sometimes downplay or dismiss these seemingly mundane portions of innovation ecosystems [16]. Yet truly radical innovations such as the jet engine, PV cell, and IC chip are rare and unpredictable; no one can 
know, with much certainty, where to look or how much money to spend in the search. Highly touted discoveries, moreover, sometimes languish indefinitely. In 1987 when President Ronald Reagan, flanked by three cabinet secretaries, introduced his administration's program for rapid commercialization of high-temperature superconductivity, he cast the new family of materials as heralding "a revolution of shattered paradigms." High-temperature superconductivity, he said, promised "a quantum leap in energy efficiency that would bring with it a host of benefits, not least among them a reduced dependence on foreign oil, a cleaner environment, and a stronger national economy" [17]. Since that time, although scientists have produced a steady stream of research results, the promised innovations have not appeared.

To extend the parallel with biological evolution, technological innovation can be understood as driven by generation of variety, new ideas that survive at least to the point of commercialization (analogous to mutations), and selection, post-commercialization winnowing as customers pick and choose among products that reach the marketplace (analogous to survival in some sort of ecological niche). Technical advance engenders variety, whether through scientific discovery (lasers, synthetic fibers such as nylon) or early $20^{\text {th }}$ century tinkering (automobiles, heavier-than-air flight) and its descendants (web apps). Entrepreneurial vision also generates variety (web apps), along with more routine sorts of business planning ("new and improved" cosmetics).

Distinguishing between generation of variety and selection helps in structuring policy portfolios. US government R\&D and demonstration projects showed nuclear power to be technically viable based on reactors originally designed for submarines. Given this new variety of energy source, utilities had to select - to decide whether or not to believe the promises of federal agencies proffering subsidies and suppliers such as General Electric and Westinghouse. Many utilities did invest, initial performance fell short of expectations, and the nuclear power boom flatlined. A few older plants have now been shut down and in the United States nuclear generating capacity seems to be in decline, as elsewhere. The segment could continue to contract. Alternatively, proposals for a new generation of small, standardized, factory-fabricated reactors could attract private capital and government subsidies, although in countries such as the United States that bought into the 1960s vision of cheap and abundant non-polluting nuclear power it seems at least as likely that memories of earlier overpromises and cost overruns will check their prospects. The nuclear narrative, then, is not over, but no one knows what the next 
act will be. In the context of climate politics, some activists view nuclear as essential to a lowcarbon future, others believe it is anathema [18].

\section{Sociotechnical Change in Context}

The intersection of Schumpeterian complexity and politics are amplified by yet another factor that plays into the challenge of energy innovation: the apparent capriciousness of human choice as a factor in technological change. Twitter, a social innovation enabled by technology, succeeded, but no one could know initially whether users would accept and adapt to 140character messaging. Indeed, market behavior routinely confounds predictions. Food and diet fashions come and go, defeating efforts at product design, prediction by market research groups, and persuasion through advertising [19]. In mobile telephony, Motorola, Nokia, BlackBerry each rose and fell over a few short years. BlackBerry's stock market valuation increased from a few billion dollars in 1997 to over $\$ 80$ billion in 2008 , then fell to less than $\$ 5$ billion; the main reason, according to a former executive: "People just didn't like it anymore" [20]. Twitter spurred follow-on innovations, as many successful products do. New applications also emerge as "enabling" innovations, such as the Internet, spread. Other examples are less obvious. The (energy intensive) Hall-Héroult process for making aluminum led to cheap cookware as well as costly high-strength aircraft alloys. While cheap aluminum cookware might have been predicted, in the first few decades after all-aluminum DC-3s began carrying paying passengers who foresaw firms such as People Express and Ryanair that pioneered low-cost vacation air travel? And while market-driven innovations such as mobile telephony spread swiftly in wealthy and poor countries alike, scarce resources - human and organizational capital especially — can hinder diffusion of both imported and indigenous innovations in developing economies [21]. Thus widespread mobile telephone networks can be found in countries unable to supply electrical power from efficient generating plants on a dependable basis. Efforts to pick apart the reasons may end in suppositions, plausible but arguable, having to do, for instance, with entrepreneurial opportunity. For instance, mobile telephony may attract a country's more capable technicians and managers, people who see the chance to build an enterprise of their own in an emerging market without the burden of inbred practices, sunk investments, and established patterns of political payoff and patronage found in the electric power industries of so many countries [22]. 
Social scientists have learned a great deal about the diffusion of innovations such as Twitter: how advertising affects the spread of, say, margarine in place of butter; how word-ofmouth (and today its digital equivalents) sells popular music and pickup trucks (automakers unveil new models in Texas for maximal impact); how birth control pills and other innovations in contraception influence individual behavior and collective phenomena such as household formation and family size; and how free public education leads young people to stay in school longer, learn more and earn more, with consequences including a greater likelihood that they will contribute to further innovation [23]. At the same time, as such examples also suggest, the larger sets of social dynamics to which innovation contributes - changes in sexual behavior, cohabitation, and marriage, labor market participation (e.g., by women), social mobility, urbanization and globalization-may, while visible, resist agreed explanations, and will certainly resist conscious steering. Over decades of interaction, cause-effect relationships become submerged in large-scale social dynamics and difficult to tease out.

\section{Three Levels of Technological and Social Change}

Our discussion of the complexity of innovation in general and for energy technology in particular is meant to highlight a problem that is largely neglected in discussions and analysis of how best to catalyze a shift toward low-carbon energy systems: there are many different analytical perspectives for understanding and trying to intervene in energy innovation, and these perspectives are neither mutually commensurable nor cumulatively coherent. One result of this multidimensionality is a Tower-of-Babel-like public discourse and policy landscape that makes even sensible discussion, let alone policy analysis, challenging if not impossible. How should we think about the land-use demands of biomass for biofuels or for solar energy production?

Distributed versus concentrated solar? Large-scale storage versus "smart" grid management for solar and wind? Storage versus natural gas backstopping? Oil from fracking versus biofuels? What does innovation and technological change even mean given such multidimensional complexity? [24] And how is action toward a single goal—decarbonization — possible amidst such complexity? As a nakedly empirical matter, analysts and advocates can assemble pretty much any set of options they prefer and justify them on the basis of a particular mix of plausible but deeply uncertain social, economic, and environmental assumptions and preferences [25]. Indeed, Andrew Stirling has showed that the published cost estimates of a variety of energy 
technologies are so uncertain as to provide no useful guidance for policy makers seeking to make choices among them [26].

In this section we begin to point toward a clarifying analytical pathway through such labyrinths of the political and technical. Social scientists have spent four decades or more teasing out the social dynamics of technological change, and in doing so have buried forever linear or deterministic notions of technological change. After all, even in the physical sciences, as Nobel prize-winning physicist Phillip Anderson noted many years ago, "at each level of complexity entirely new properties appear" and "entirely new laws, concepts, and generalizations are necessary" [27]. While the vast literature on sociotechnical systems generally aims to make clear that technologies cannot be understood apart from the complex social contexts of their develop and use, here we want to take a different tack and look, as it were, through the big end of the telescope to recover what it is about technologies themselves that makes them useful in the world despite the complexities of sociotechnical context [28]. Thus, we think it uncontroversial to observe that technologies can be explicitly considered in terms of end products that perform valued functions (some of them vital, others more nearly matters of convenience) [29]. Childhood vaccinations, for example, alter our immune system so we can expect to live to old age; electric toothbrushes, depending on how they are used, may help us avoid dentures. At the simplest level, then — Level 1 (see the table) —an Airbus flies us from New York to London with remarkable safety. Smartphones adjust automatically to London time and make it easy to reconfirm hotel reservations. At some point not too far in the future we hope we may ride to the hotel in a driver-less, electrically-powered taxi. 


\section{Technologies, Networks, and Systems}

\section{Level 1: Complex Technologies}

- Progressive incremental performance improvement over many decades (commercial aircraft).

- Increased technical complexity in a largely closed, engineered, manageable system with transparent performance metrics (fuel consumption, cost per seat mile, accident rate).

- Uncertainty reduced with accumulating technical knowledge and operating experience (mathematical models for prediction of aircraft performance).

\section{Level 2: Complex Technological Networks}

- Core system reliability coexists with ancillary dysfunction (airport delays, noise).

- Continually increasing system complexity in a partly open, difficult-to-manage sociotechnical system (air traffic control, critical for accident prevention and at the same time a cause of delays and fuel-wasting routing patterns chosen for safety).

- Uncertainty managed through appropriate institutional and social arrangements (agreed rules for separation of aircraft in three dimensions; English as a standard language for pilots and air traffic controllers).

\section{Level 3: Complex Sociotechnical and Earth Systems}

- System boundaries disappear, system dynamics variably unpredictable (automation degrades piloting skills, a new cause of accidents; jet engine emissions affect stratospheric chemistry).

- Uncertainty grows with system complexity (long-term sustainability of mass air travel).

Note: This table uses aircraft/air travel as a familiar, easily comprehended example. At present aircraft are minor, not major, sources of greenhouse gas emissions, but their share is growing relative to other sources. Fuel, moreover, accounts for one-third or more of airline operating costs, so that energy pricing and fuel-saving innovations in airframe and engine design have been significant factors in competition.

At Level 1, technologies evolve through ongoing interactions between those who do the development and those who use new products and systems. Two modes of interaction predominate. For expensive, long-lived capital goods such as commercial aircraft, interactive dialog between suppliers and customers - manufacturers of airframes and engines on one side and airlines, initial or lead customers especially, on the other-becomes part of the basis for design decisions; major attributes may emerge only after years of information exchange, informal discussion, and negotiation. Much the same is true-design decisions following from and based upon dialog and negotiation - for central-station electric generating plants, enterprise software systems, and highway bridges paid for by public agencies but designed and built by private firms. For consumer products such as smartphones and health insurance plans, on the other hand, latent demand is difficult to gauge. Potential customers may not be able to easily or accurately envision what an innovation will mean for them personally; they do not have 
"business plans" in their heads, unlike airlines shopping for next-generation planes from Boeing or Airbus. Market research may yield useful predictions for a new type of breakfast cereal, less often for take-up of innovations such as mobile telephony, which grew for years at rates far outstripping projections [30].

Technologies also function as parts of more complex networks-Level 2. The network label suggests the importance of linkages —working relationships, structured in some waybetween actors that may include business firms and their customers, state agencies, intergovernmental organizations, and international regimes. An effective malaria vaccine would count as a scientific and medical breakthrough with profound effects in large parts of the world, and not just in preventing illness: economic output, for instance, depends ultimately on what individuals accomplish and healthy people are more productive. Gaining the benefits of malaria or other vaccines, in less developed countries especially, may require adjustments in health care delivery networks. For communicable diseases like measles, population-wide effectiveness depends on vaccination of a sufficiently large fractions of people to achieve community (or herd) immunity, at which point a kind of threshold effect kicks in and the likelihood of transmission to the unvaccinated minority falls to some very low level. Arresting and possibly eradicating such diseases then requires not only effective vaccines but effective means for reaching large numbers of people. This is a matter of organization and management: persuading skeptics of the benefits; negotiating arrangements with local political figures who may have their own agendas; developing standardized procedures; training workers, perhaps locally hired. Then too some vaccines must be refrigerated. The electrical power to accomplish this seemingly mundane task, or to make ice, may or may not be consistently available in low-income countries.

Generally speaking, societies have learned to design, build, and operate these Level 2 networks. Learning is possible because the network goal is to deliver the Level 1 function that people depend on. Failure is therefore both conspicuous and clearly defined. When failures occur, the causes must be diagnosed and future failures of a similar sort prevented, in principle if not always in practice. Standard time zones came about in response to confusion that caused train wrecks. As railway networks grew and service became routine and reliable, firms such as Armour and Swift could take advantage of the new capabilities to revolutionize meatpacking and distribution. In practice, failures occur: trains and jetliners still crash, as do electrical grids, but the grids in wealthy countries are pretty reliable, and when they become unreliable customers get 
very upset. Organizational competence - keeping refrigerated trains running on time - has always been a key to using technology effectively, and in principle the organizations that manage Level 2 networks must develop and exercise stewardship over the knowledge and skills needed to ensure that Level 1 technological components function reliably.

Nonetheless, a key point we want to highlight is that this sort of organizational competence is possible because the Level 1 technology provides clear enough feedback signals on success and failure to allow for competence to exist, as an operational construct, one with measures that help guide managers. If the organizations were, instead, held accountable for, say, improving the economic performance of a nation in Sub-Saharan Africa through the development and deployment of malaria vaccines, competence would be both a lot harder to achieve and to demonstrate. Perhaps poor public institutions obstruct growth even in the presence of a good vaccine. Or perhaps the vaccine fails but successful investments in delivering vocational education builds development capacity along different pathways.

Now we are at Level 3. Here complexity becomes pervasive and outcomes of innovation difficult or impossible to predict [31]. As component parts in software-intensive digital systems, IC chips and the automation they catalyze have contributed, inarguably if murkily, to jobless growth and wage inequality in the United States and elsewhere, which in turn feeds into political reactions that help determine national policies on a wide variety of issues with seemingly no connection to information technology, such as trade policies, education and training programs, and the social safety net. What we emphasize here is that intervening in the design and use of software-intensive digital systems is not, regardless of attempts at participatory design and "high road" work organization, useful or even one of the available tools for addressing the labor market and distributional consequences of those systems. This is in marked contrast to Level 2, where complexities may be very great indeed, but intervention is still disciplined by feedbacks from the performance of the Level 1 technology, and outcomes can be reasonably pursued on that basis.

In the early decades of the US auto industry, hundreds of firms competed to sell vehicles powered by gasoline engines, storage batteries, and steam-Level 1 innovations, products of the state of the evolving engineering arts [32]. Purchasers eventually chose gasoline engines and the oil industry boomed. A steady stream of, again, Level 1 innovations in exploration, extraction, and refining kept fuel prices low [33]. Cars and trucks needed hard-surfaced roads and highways, 
and governments (local, state, and federal) provided them (financed in part by the policy innovation of fuel taxes). This Level 2 network response brought increases in accidental injury and death arrested only in the 1960s by (federal) safety standards, regulations that addressed Level 2 dysfunction through Level 1 engineering, again by means of relatively standard engineering approaches [34]. By this time, systemic or Level 3 complexity had long since emerged as well. Low-cost personal vehicles enabled families that could afford detached suburban homes to move outward from cities. Others moved inward from rural America, as Level 1 agricultural innovations, including mechanization (farmers sometimes adapted Model Ts as tractors or barnyard power sources) pushed up productivity and farm families that could not keep pace left the land for wage work in towns and cities. The trucking industry (Level 2) grew to supply wholesale distribution and retail sales outlets far from fixed railway lines; refrigerated tractor-trailers, for instance, took meat from terminals to supermarkets scattered through lowdensity suburbs [35]. As agricultural employment fell, service-sector employment rose, along with white-collar jobs in goods-producing firms; veritable armies of clerical and administrative workers were needed to staff rapidly growing new enterprises with multiple divisions and many lines of business [36]. Suburban sprawl, finally, brought seemingly unmanageable traffic congestion to some parts of the United States, contributing (in unmeasurable ways) to modest recent levels of counter-migration to cities, presumably accompanied by modest reductions in GHG emissions, at least from transport.

Climate change is a Level 3 phenomenon. It is the result of imperfectly understood mechanisms that encompass, for example, wealth distribution and appetite for luxury goods and the politics of nuclear energy, not to mention the plate tectonic movements, unpredictable and immune to human influence, that led to the Fukushima disaster. And of course the nuclear reactors that provide dependable, $\mathrm{CO}_{2}$-free electrical power were developed initially for making fissile material for bombs, which led to a Level 2 international regime that attempts to regulate proliferation of enriched uranium, plutonium, and bomb-making know-how. Fukushima, finally, had consequences far beyond Japan, for example in contributing to the political decision by Germany to switch from nuclear power to renewable sources, a risky attempt to break free of inertia and lock-in that, to date, has led to both rising energy costs and rising $\mathrm{CO}_{2}$ emissions from the electrical power sector. Sweden made a similar choice, later reversed. If sustained and successful, Germany's approach will contribute to significant advances in renewable energy 
sources that can be integrated into an existing grid system. Yet the benefits lie well in the future and the transition costs will be forbidding and must be paid first.

Level 3 problems cannot be fully analyzed and resolved on their own terms. Societies do not know how to intervene to achieve predictable outcomes: the variables are too many, their interconnections too uncertain for cause-effect relationships to be derived [28]. Nobody can know what would follow from an attempt to end Iran's nuclear bomb program by force (or through treaty, for that matter - but the reasonable belief is that violence begets unintended consequences more quickly and unmanageably than diplomacy). Nor can anyone know how high a price on carbon would be needed to induce necessary restructuring of the world energy system without also inducing serious economic disruption, much less how this restructuring would proceed. With strong price signals energy systems would certainly change, but not in predictable ways. In low-income countries, big increases in energy prices would be calamitous for billions of people. In principle, prices could be (further) subsidized, and richer countries might perhaps offset some of these expenditures. In practice, promises to compensate those disadvantaged by rising energy prices have limited credibility within countries and interstate agreements have still less, absent supranational authority, which does not exist [37]. Would Level 3 benefits outweigh the costs? The question is unanswerable, even incoherent. If the problem is $\mathrm{CO}_{2}$ in the atmosphere, mitigation of climate change will have to be approached using Level 1 technologies whose performance conditions the effectiveness of Level 2 organizations and networks. Doing so effectively requires an appreciation of energy technologies and systems, how they differ from one another and from non-energy technologies, and of the characteristics of industries and markets that give rise to energy-technology innovations.

\section{What's Special About Energy-Climate Innovation?}

Two Level 1 considerations make energy innovation inherently different from, say computers, aircraft, or birth control devices. First, energy as delivered to the end-user is a commodity possessing standardized attributes, such as those of gasoline of a given grade or electrical power supplied within a prescribed range of voltage and frequency values. In this respect, energy is like tinplate (the coated steel from which "tin" cans are made) or newsprint. Of course, just as tin cans, once filled, or newspapers, once printed, provide differentiable products, so do at least some varieties of energy services. For an energy end-user, the joule of energy 
provided by gasoline is indistinguishable from the one provided by switchgrass-based biofuel or a PV cell. Electricity and gasoline (within grades) thus sell on price alone. A consumer might prefer her electricity to be generated by a wind rather than steam turbine, but if the steam turbine already exists, switching over to wind provides her nothing but psychic satisfaction, and even if the kilowatt hours are priced the same the costs of displacing the existing technology may be very high indeed. When smartphones came on the market, on the other hand, they provided enormous increases in functionality over the old mobile phones (not to mention over bulky cameras, wall calendars, and road atlases) and users were happy to pay for the difference. End products that consume energy — smart phones, cars, and houses alike — can be differentiated through design features, giving business firms powerful incentives to innovate. The commodity nature of energy offers few such incentives for energy generation (although there are exceptions, such as better battery technologies that extend recharge intervals for electric vehicles). The dearth of such incentives reinforces justifications for public policies to strengthen private incentives for innovation.

Second, physical laws impose upper bounds on energy conversion processes, by telling us that energy systems cannot improve without apparent limit, as familiar digital technologies seem to. Smartphone apps multiply indefinitely, as does computer speed and power (although these will at some point bump up against quantum effects). PV efficiency, on the other hand, has limits that were apparent from the beginning (likewise rooted in quantum mechanics), and batteries, no matter how the design of lithium-ion systems might be tweaked, will always and necessarily give back less energy on discharge than put in during charging, just as air conditioners will always cause more heating than cooling.

At the same time, energy-system innovation goes on continuously. Architects and engineers learn to balance heating and air conditioning loads in buildings more effectively, minimizing spatial and temporal temperature variations to improve comfort levels while saving energy. PV firms fine-tune their manufacturing processes to raise production yields by fractions of a percentage point and automakers reduce engine friction and accessory losses to increase mileage ratings by a tenth of a mile per gallon. As these sorts of advances accumulate, they create moving targets for alternative technologies: battery-electric and fuel cell-electric powertrains must compete with increasingly efficient conventional engines incorporating 
innovations such as direct in-cylinder fuel injection that themselves represent considerable advances in the "state of the art" [38].

The point we want to emphasize is that the Level 1 commodity-like attributes of energy (although not, of course, energy services), and the limits of physical laws, simply add to the difficulties of thinking about how to move to a low-carbon energy system for reasons having to do with Level 3 consequences. Technological incumbents always resist being replaced-that's what Luddism is all about — but when the product being delivered to the end-user doesn't offer either performance or price improvements, the rationale for change is that much weaker.

\section{Breaking System Momentum}

Resistance to technological change is a Level 3 phenomenon discussed by the historian Thomas Hughes and others. Large-scale sociotechnical systems possess inertia, or momentum, that tends to channel innovation along established trajectories, sustained by interdependencies among technological systems and the institutions, interests, and practices that surround, contain, and constrain them [39]. Germany's Energiewende, or energy transition, provides an illustration, still unfolding, of complications following from a deliberate effort to steer large-scale systems in some new direction. With the last of Germany's nuclear plants scheduled to close in 2022, the Energiewende plan calls for renewables to supply half the country's electricity by 2030 and 80 percent by 2050, when primary energy consumption is to be half its 2008 level, and GHG emissions to decline by 80 percent or more relative to 1990 [40]. Legislation passed in 2000 spurred heavy ongoing investments in wind energy and solar power, and Germany today has far more installed capacity today than any other European country. Even so, wind and solar produce power only when the wind blows and the sun shines, and in 2015 were expected to generate no more than about 15 percent of Germany's electricity [41]. For the next decade or so, perhaps longer, the country must rely more heavily on fossil fuels or else change its policy. German utilities have been building new coal-fired plants and importing electricity from countries such as Poland that generate much of their power from coal; within Germany, entire towns are being moved to facilitate strip mining of lignite, a soft brown coal that, while abundant, is one of the most polluting of all fuels [42].

Large-scale technological and institutional change brings risks and rewards, and German utilities worry about their profit-and-loss statements. While momentum is building in newly 
emerging systems, entrepreneurial opportunities loom large and losers may not be fully aware of their position. Once momentum has been built, sunk costs underpin systemic inertia [43]. And when a mature system is threatened, losers get plenty of warning and mobilize in opposition, fighting to block or at least to slow change. Because the benefits of environmental policies tend to be diffuse, perhaps imperceptible in the short term, innovators and entrepreneurs may face years of work in assembling and then holding together political coalitions that will back their plans, positions, and preferred policies without too much compromise.

Systems of governance matter too. Strong political currents underlie Energiewende. Germany's Green Party emerged in the early 1970s and became part of a coalition government as long ago as 1998. While we admire the ambition and risk-taking (both political and technological) embodied in Germany's Energiewende, we emphasize that the success of this nation-scale effort is far from settled. Even if enormous Level 1 challenges such as energy storage for backing up renewable energy sources are overcome, the Level 2 political, economic, and organizational obstacles remain formidable. Initial results, which include rising energy costs and rising carbon emissions, are not likely to be reversed soon. In the very different US political system, long-term plans such as Energiewende have no real feasibility. Indeed, Congress has failed to pass a single major piece of environmental legislation since the Clean Air Act amendments of 1990, never mind a meaningful national energy "strategy," despite declarations of intent by US presidents going back to Richard Nixon [44]. The abdication by Congress has left a vacuum that the courts have perforce had to fill, through rulings, finalized after seemingly interminable delays, on increasingly strained interpretations of executive branch regulatory authority based on laws passed at a time when climate change had no visibility beyond the scientific community [45]. Movement away from coal-fired power plants has begun, yet the impetus has come mostly from economic forces (such as cheap natural gas from fracking) combined with responses to tightening regulatory standards on pollutants including mercury and sulfur dioxide. Utilities have decommissioned older, inefficient, and maintenance-intensive coal plants that they fear will be unable to meet future standards, at least without costly retrofits, and because some of these plants, perhaps held in reserve for back-up and to provide peaking capacity, cost more to run than they bring in. By replacing them with high-efficiency gas turbines and combined cycle plants burning cheap natural gas, utilities expect increased profitability. $\mathrm{CO}_{2}$ emissions also fall, but this is incidental to their calculations except as a buffer 
protecting against possible regulatory standards enacted at some future time. Although a number of technical approaches to carbon capture and storage (CCS) have been demonstrated, so that utilities could if required remove $\mathrm{CO}_{2}$ from the flue gases of coal-burning plants - and plants that run on natural gas or for that matter biomass - they have no reason to do so unless legally compelled. In the United States, it would take a considerable feat of political architecture to force CCS on unwilling utilities and their customers. No other country has managed, either.

Still, we can envision transformation of electric power generation, the largest source of global GHG emissions. Technical means exist, and further innovation will accompany concerted efforts to steer down new pathways. Energy conservation in buildings, too, seems reasonably straightforward, with a large inventory of proven Level 1 technologies available. Stronger incentives would speed implementation, again fostering, as a quite predictable consequence, ongoing incremental innovation. Much the same is true for many industrial processes. Transportation, by contrast, second to electric power generation as a source of GHGs globally, poses greater difficulties, technical and infrastructural.

Although incremental innovations sometimes culminate in radical technology change, as in the case of the Internet, no one should count on technological breakthroughs to alter the momentum of carbon-intensive energy systems. Genuine breakthroughs in energy technology have been rare. The most recent, nuclear power and solar PV, date from the middle of the last century. Most of today's battery concepts, derived from well-known principles of electrochemisty, have been around for decades. Fuel cells, reduced to practice in the 1960s for the Gemini spacecraft, operate on principles known since the first half of the $19^{\text {th }}$ century, and of course wind energy, hydropower, and biofuels go back still farther. The last energy technologies to spark waves of Schumpeterian transformation were steam power in the $18^{\text {th }}$ century, centralstation electric power generation in the $19^{\text {th }}$ century, and oil and gas in the first half of the $20^{\text {th }}$ century. Momentum will be shifted by means of large numbers of individually small innovations, few of these with much visibility. To considerable extent, and depending on policy incentives, the pace will be set by service lifetimes of current Level 1 technologies: coal-fired power plants; residential and commercial buildings with leaky windows and poorly regulated heating and air conditioning systems; gas-guzzling light trucks bought as personal vehicles.

\section{The Future of Energy-Climate Innovation}


Our analysis leads us toward emphasizing the need to understand and focus on Level 1 innovation and (to a lesser extent) Level 2 networks, rather than on efforts to better understand, model, and steer complex and indeterminate Level 3 sociotechnical and Earth systems as a basis for action. In this concluding section we want to highlight what we see as an important consequence of this analysis for policy making. When policy goals cannot be adequately monetized, as for environmental impacts or national security, only government can drive innovation. Government-driven Level 1 innovations have often been pursued - and often at very large scales - through the pursuit of public works, justified politically on their capacity to provide widely shared public goods. Major government investments have been dedicated toand social benefits derived from - this approach, which we believe has been neglected in climate change policy discussions.

Here as earlier we focus on the United States, the country we know best and something of a bellwether in technology and science, if not in energy-climate, policy. The nation was designed in the $18^{\text {th }}$ century with a weak and fragmented federal system to make any sort of big change in policy difficult first to enact and then to implement. Political theory and policy history tell us that the United States exhibits a "strong structural bias within our existing lawmaking institutions in favor of government acting slowly and incrementally" [46]. The search for practicable technological pathways to reducing the risks from human interference in the climate system demands that the realities of democracy, private-sector innovation, and climate change must all be taken into account. If one understands climate change mitigation as a Level 3 problem of complex sociotechnical systems interacting at the scale of global societies and indeed the Earth system itself, then neither the history of policy, nor of innovation, offers any very convincing precedents for how to modify system performance, deliberately and with outcomes both desired and foreseeable [47]. This situation feels unsatisfactory and paradoxical: climate change plays out due to the Level 3 complexities; surely the solutions must lie in modifying those complexities as well?

We are making the case that this intuition is contradicted by the nature of both technological innovation, and its complex co-evolution with society. Taking the essence of mitigation to be a Level 1 technology problem - a problem of innovations, mostly incremental but in large numbers and widely implemented - the history of innovation teaches us that the most productive policy pathways for rapid advance and performance improvement are likely to be 
those that are pursued at that same level, Level 1, rather than efforts to steer the complex global energy system, in its entirety, in a new direction, as attempted by the Kyoto Protocol. The essence of the energy-climate innovation challenge is in some ways summed up by President Barack Obama's decision late in 2015 to reject the Keystone pipeline, which was to transport oil from the tar sands of western Canada to the refineries of the American Gulf Coast [48]. The rejection marked the culmination of a bruising, years-long political battle, with environmentalists arguing that producing oil from the tar sands catastrophically accelerates global warming, and opponents (mostly conservative Republicans, but some Democrats as well) arguing that it would create needed jobs and economic opportunity. The president's rejection, in the end, was a political gesture made to signal to the world his environmental bona fides on the eve of another international climate conference. But the rejection was made politically and economically possible by the low cost of oil worldwide, and the rapid expansion of cheap natural gas due to fracking, which combined to render the pipeline unnecessary for America's energy future. Meanwhile, when oil prices begin to climb once more, as they assuredly will, the tar sands will find their way into energy markets through other means. Until the Level 1 problem of carbon emissions is solved through innovation, the Level 3 problems of climate change will remain intractably political.

For a strategic approach to climate mitigation that would suit the American experience, and we believe other market democracies as well, we point toward a history of major public investments justified in terms of their capacity to deliver public goods. Indeed, the US government has proven itself to be remarkably successful at fueling Level 1 innovation over long periods of time and across many classes of technology through public spending for public missions. Pretty much the entire technological backbone of post-World-War-II modernity got jump-starts from Defense Department investments in the absence of a market rationale [49]. And while national security has been the most prominent mission since World War II, from early in the $19^{\text {th }}$ century economic development and civic improvement were common objectives of spending by federal, state, and local governments. In most cases, these bodies relied contracted with the private sector for construction of roads, dams, waterworks, sewage systems, and airports, as well as for production of steel-hulled, steam-powered warships and later for antibiotics, synthetic rubber, nuclear submarines, and jet aircraft. 
Engineers paid through government contracts learned to design and fabricate structurally sound railway and highway bridges of unprecedented length. The link between sanitation and health, established in the middle part of the $19^{\text {th }}$ century through epidemiological studies of dread diseases such as cholera and typhoid, spurred construction of water supply and sewerage systems [50]. Pioneering innovations in design and operating practices originated in England, Germany, and elsewhere in Europe and were transferred to countries including the United States, where, for example, grade levels in Chicago's urban core were raised by up to twelve feet so sewers would drain [51]. Municipal governments planned and paid for much of this sort of work, pushed by boosters, reformers, civic leaders, and medical professionals (who might join forces on local boards of health), "improvers" who, among other things, saw in waterworks and sewerage systems a means of setting their city off from others so as to attract investment and grow, and by voters who saw not just the quality of urban life but their very lives and livelihoods at risk.

The parallel with national security holds a related lesson: procurement contracts for production quantities of goods, whether repeating firearms or computer-controlled machine tools (or guided missiles) - is a powerful tool for fostering innovation with multiple (and often unanticipated) spinoffs. For centuries, until aviation spurred a shift away from arsenal systems, many military technologies originated in government facilities. Slow-moving and stodgy, these could not keep pace with aviation technology during the First World War and governments had no choice but to turn to firms run by visionary engineers and entrepreneurs [52]. The scope for private industry widened with World War II and Cold War, generating repeated bursts of technological creativity and a flood of innovations. During the Cold War, procurement contracts, so often overlooked in policy discussions, enabled numerous major innovations to take root and progress toward maturity: digital systems, semiconductors, and then the Internet; fiber-reinforced composite materials; satellites and GPS.

The national security rational has also justified public investment in technological infrastructure. In the $19^{\text {th }}$ century defense provided justification for spending on railroads (to speed mobilization), and in the $20^{\text {th }}$, the Defense Highway Act of 1956 funded construction of the Interstate Highway system under the pretext of Cold War mobilization and civil defense. Non-defense public works investments have included support for generation and distribution of electricity, as through hydroelectric facilities in many parts of the world, demonstration projects in the early years of nuclear power, and indeed public ownership of energy production facilities 
(Électricité de France; in the United States legacies of the Progressive Era such as the Tennessee Valley Authority and the hydroelectric projects of the Bureau of Reclamation and Army Corps of Engineers).

The public-goods justification itself contrasts markedly with the main rationale that has driven climate politics for three decades - the meting out of punishment to GHG emitters for the unintended consequences of locked-in Level 3 systems, through taxes, cap-and-trade schemes, mandated emissions reductions, and so on, in order to force a shift away from carbon-based energy. It focuses instead on expanding opportunity and benefits for all, and in particular it enfranchises rather than alienates the private sector, which is the source of the innovation and products that are the tangible, Level 1 manifestation of expanding public welfare. It is a bruteforce approach to technological innovation and diffusion, and this is precisely its virtue. Americans do not oppose clean, cheap, universally available energy achieved through wealthcreating innovations driven, in turn, by public investment [53].

Such a policy strategy would resemble those for ensuring public health and national security, and as we are emphasizing, therefore has strong and generally positive historical precedent. Pressure from below forced governments to respond to demand for clean water and sewerage services as cities expanded during the $19^{\text {th }}$ century. Economic development motivated much of the investment in infrastructure over these same years, such as railroads. While the vast fortunes made by railway builders and other Robber Barons led to a reaction against some of these policies, the immensity of these nation-building accomplishments shows the potential of government-led programs to build or transform large-scale systems. The Cold-War creation of the nation's information and communication infrastructure demonstrates a similar scale of accomplishment. The parallels with climate change, partial though they may be, hold a compelling lesson: government spending for public missions can both stimulate innovation by the private sector and transform sociotechnical systems to deliver broad societal benefits.

\section{Acknowledgements}

An earlier version of this paper was prepared for the workshop on "Opportunities in Crises: Technogoverning Sustainable Landscapes," University of Virginia, Charlottesville, VA, USA, March 18, 2015. The authors thank the participants for helpful comments at the workshop and afterward. The paper draws on past work for the Consortium for Science, Policy \& Outcomes 
with support from the Clean Air Task Force, Bipartisan Policy Center, Nathan Cummings Foundation, and the David and Lucile Packard Foundation; see in general www.cspo.org/content/energy-innovation-further-reading\#overlay-context=projects/dod-energy.

\section{References and Notes}

[1] See, e.g., Nicholas Stern, The Economics of Climate Change: The Stern Review (Cambridge, UK: Cambridge University Press, 2007); Adonis Yatchew, "Economics of Energy, Big Ideas for the Non-Economist," Energy Research \& Social Science, Vol. 1, 2014, pp. 74-82.

[2] For an early discussion of technological lock-in, termed momentum, see Thomas Hughes, "Technological Momentum in History: Hydrogenation in Germany 1898-1933," Past and Present, No. 44, 1989, pp. 106-132. The idea gained currency more broadly when adopted by economists; e.g., Brian Arthur, "Competing Technologies, Increasing Returns, and Lock-In by Historical Events,” Economic Journal, Vol. 99, 1989, pp. 116-131.

[3] John A. Alic, “The Radical Uncertainty of the Future," Technological Forecasting and Social Change, Vol. 62, 1999, pp. 147-150.

[4] "Roughly, by a complex system I mean one made up of a large number of parts that interact in a nonsimple way." Herbert A. Simon, "The Architecture of Complexity," Proceedings of the American Philosophical Society, Vol. 106, No. 6, 1962, pp. 467-482; quotation from p. 468.

[5] Patrick Suppes, “Explaining the Unpredictable,” Erkenntnis, Vol. 22, Nos. 1/3, 1985, pp. 187-195.

[6] Yanguang Li and Hongjie Dai, "Recent Advances in Zinc-Air Batteries," Chemical Society Reviews, Vol.43, 2014, pp. 5257-5275.

[7] E.g., Anna Bergek, Staffan Jacobsson, Bo Carlsson, Sven Lindmark, and Annika Rickne, "Analyzing the Functional Dynamics of Technological Innovation Systems: A Scheme of Analysis," Research Policy, Vol. 37, 2008, pp. 407-429.

[8] "Interview: Nicholas Bloom," Econ Focus [Federal Reserve Bank of Richmond], Second Quarter 2014, pp. 22-26; quotation from p. 25. 
[9] Schumpeter's hugely influential 1942 book Capitalism, Socialism and Democracy (5th edition, London: Allen and Unwin, 1976) is the most closely associated of his works with images of creative destruction as the driving force of capitalism.

[10] Wiebe E. Bijker, Thomas P. Hughes, and Trevor J. Pinch, eds., The Social Construction of Technological Systems: New Directions in the Sociology and History of Technology (Cambridge, MA: MIT Press, 1987).

[11] Edith Tilton Penrose, "Biological Analogies in the Theory of the Firm," American Economic Review, Vol. 42, 1952, pp. 804-819; quotation from p. 804.

[12] John A. Alic, Trillions for Military Technology: How the Pentagon Innovates and Why It Costs So Much (New York: Palgrave Macmillan, 2007), pp. 111-112.

[13] Nathan Rosenberg, "Learning by Using," in Inside the Black Box: Technology in Economics (New York: Cambridge University Press, 1982), pp. 120-140.

[14] Monthly Energy Review January 2015, DOE/EIA-0035(2015/01) (Washington, DC: Energy Information Administration, January 28, 2015), Table 8.1, p. 117.

[15] See, e.g., Daniel A. Levinthal, “The Slow Pace of Rapid Technological Change: Gradualism and Punctuation in Technological Change," Industrial and Corporate Change, Vol. 7, 1998, pp. 217-247.

[16] As Nathan Rosenberg observed many years ago, "Schumpeter never quite over-came his preoccupation with the charismatic aspects of leadership and its role in instituting changes in the operation of the economic system. As a result, his own towering intellectual leadership in this area has led to an excessive concern with ... the circumstances surrounding the initial 'breakthrough,' and to a neglect of .... the cumulative impact of relatively small innovations ...." Nathan Rosenberg, “Technological Change in the Machine Tool Industry, 1840-1910,” Journal of Economic History, Vol. 23, 1963, pp. 414-43; quotation on p. 424.

[17] One of us was present in the ballroom of the Washington Hilton when President Reagan, reading from a teleprompter, spoke of "shattered para-digims." "Remarks at the Federal Conference on Commercial Applications of Superconductivity, July 28, 1987,’ http://www.reagan.utexas.edu/archives/speeches/1987/072887a.htm. 
[18] Michael Specter, "How Not to Debate Nuclear Energy and Climate Change," New Yorker, December 18, 2015.

[19] Schumpeter: "It was not enough to produce satisfactory soap, it was also necessary to induce people to wash - a social function of advertisement that is often inadequately appreciated." Quoted on p. 258 in Thomas K. McCraw, Prophet of Innovation: Joseph Schumpeter and Creative Destruction (Cambridge, MA: Harvard University Press, 2007). [20] Felix Gillette, Diane Brady, and Caroline Winter, "The Rise and Fall of BlackBerry: An Oral History," Bloomberg Businessweek, December 9-December 15, 2013.

[21] John A. Alic, "Organizational Competence: Know-How and Skills in Economic Development," Technology In Society, Vol. 17, 1995, pp. 429-436.

[22] Deterring Corruption and Improving Governance in the Electricity Sector (Washington, DC: World Bank, April 2009).

[23] Everett M. Rogers, Diffusion of Innovations, 5th edition (New York: Simon \& Schuster, 2003).

[24] The nine authors of Virginia A. Dale, et al., "Indicators for Assessing Socioeconomic Sustainability of Bioenergy Systems: A Short List of Practical Measures," Ecological Indicators, Vol. 26, 2013, pp. 87-102, discuss 16 different indicators.

[25] Robert S. Pindyck, The Use and Misuse of Models for Climate Policy, Working Paper 21097 (Cambridge, MA: National Bureau of Economic Research, April 2015).

[26] Andy Stirling, “Keep it Complex,” Nature, Vol. 468, 2010, pp. 1029-1031.

[27] P.W. Anderson, "More Is Different: Broken Symmetry and the Nature of the Hierarchical Structure of Science," Science, Vol. 177, August 4, 1972, pp. 393-396; quotations from p. 393. [28] Daniel Sarewitz and Richard Nelson, "Three Rules for Technological Fixes," Nature, Vol. 456, 2008, pp. 871-872.

[29] Braden Allenby and Daniel Sarewitz, The Techno-Human Condition (Cambridge, MA: MIT Press, 2011), pp. 31-85. Also Bruno Latour, "Where Are the Missing Masses? The Sociology of a Few Mundane Artifacts," in Wiebe E. Bijker and John Law, eds., Shaping Technology/Building Society: Studies in Sociotechnical Change (Cambridge, MA: MIT Press, 1992), pp. 225-258. 
[30] “A Survey of Telecommunications: Cutting the Cord," Economist, October 7, 1999.

[31] As will be clear, our typology differs from others featuring three levels, as for example

Frank W. Geels, “Technological Transitions as Evolutionary Reconfiguration Processes: A Multi-Level Perspective and a Case-Study," Research Policy, Vol. 31, 2002, pp. 1257-1274; and Frank W. Geels and Johan Schot, "Typology of Sociotechnical Transition Pathways," Research Policy, Vol. 36, 2007, pp. 399-417. Geels and others who have contributed to this literature adopt largely theoretical perspectives in seeking to explain relatively straightforward technological shifts: the case study alluded to in the title of the first paper cited above deals with the transition at sea from sail to steam, the history of which has been written. Further, and despite occasional protestations to the contrary, little of this work addresses policy. Our concerns lie rather with what a fresh look at Level 1 technologies might tell us about practical policies and their implementation pertaining to climate change.

[32] Rudi Volti, “A Century of Automobility,” Technology and Culture, Vol. 37, 1996, pp. 663685.

[33] John L. Enos, Petroleum Progress and Profits: A History of Process Innovation (Cambridge, MA: MIT Press, 1962).

[34] Ann Johnson, Hitting the Brakes: Engineering Design and the Production of Knowledge (Durham, NC: Duke University Press, 2009).

[35] Alfred D. Chandler, Jr., The Visible Hand: The Managerial Revolution in American Business (Cambridge, MA: Harvard University Press, 1977).

[36] Claudia Goldin, “America's Graduation from High School: The Evolution and Spread of Secondary Schooling in the Twentieth Century," Journal of Economic History, Vol. 58, 1998, pp. 345-374.

[37] But see Robert O. Keohane and David G. Victor, "The Regime Complex for Climate Change," Perspectives on Politics, Vol. 9, 2011, pp. 7-23.

[38] Lindsay Brooke, "Future ICEs: What Comes After 2025" Automotive Engineering International, July 2015, pp. 18-24. 
[39] "[C]haracteristics of technological momentum" include "acquired skill and knowledge, special-purpose machines and processes, enormous physical structures, and organizational bureaucracy." Thomas P. Hughes, “Technological Momentum," in Merritt Roe Smith and Leo Marx, eds., Does Technology Drive History (Cambridge, MA: MIT Press, 1994), pp. 102-113; quoted phrases from p. 108. Many others, especially economists, also discuss technological lockin. We adopt Hughes's language, less mechanical seeming, to keep the focus on institutions and politics rather than narrower economic phenomena.

[40] Second Monitoring Report: "Energy of the Future” (Berlin: Federal Ministry for Economic Affairs and Energy, March 2014), p. 4.

[41] EU Energy, Transport, and GHG Emissions: Trends to 2050 (Luxembourg: European Union, 2014), p. 111.

[42] Stefan Nicola and Ladka Bauerova, "Dirtiest Coal's Rebirth in Europe Flattens Medieval Towns," Bloomberg Businessweek, January 6, 2014; Arne Jungjohann and Craig Morris, The German Coal Conundrum: The Status of Coal Power in Germany's Energy Transition (Washington, DC: Heinrich Böll Stiftung, June 2014).

[43] Hughes, in "Technological Momentum in History" (endnote 2) emphasized the financial constraints of the firms he studied, along with the human and organizational capital represented by the knowledge and skill of their technical and managerial employees. Hughes was primarily concerned with how momentum was built, not how it could be altered; in his later work he stressed the system more than the enterprises that were part of it, and financial management receded in his analyses; as a historian of technology he perhaps also wanted to differentiate his approach from that of business history.

[44] www.cc.com/video-clips/n5dnf3/the-daily-show-with-jon-stewart-an-energy-independentfuture.

[45] Jody Freeman and David B. Spence, “Old Statutes, New Problems,” University of Pennsylvania Law Review, Vol. 163, 2014, pp. 1-93.

[46] Richard J. Lazarus, "Super Wicked Problems and Climate Change: Restraining the Present to Liberate the Future," Cornell Law Review, Vol. 94, 2009, pp. 1153-1233; quotation from p. 1180. 
[47] For a complementary, historically oriented perspective, see Vaclav Smil, Energy

Transitions: History, Requirements, Prospects (Santa Barbara, CA: Praeger, 2010).

[48] Coral Davenport, "President Rejects Keystone Pipeline, Invoking Climate," New York

Times, November 7, 2015.

[49] Daniel Sarewitz and John Alic, “Accelerating Technological Advance for Climate Change:

Lessons from Sixty Years of U.S. Innovation Policy,” Testimony before the U.S. Senate

Committee on Energy and Natural Resources, December 2, 2009,

cspo.org/legacy/library/091214F0YX_lib_AlicSarewitzTest.pdf.

[50] Annabel Ferriman, “ $B M J$ Readers Choose Sanitation as Greatest Medical Advance since 1840,” British Medical Journal, Vol. 334, 2007, p. 111.

[51] Joel A. Tarr, "The Search for the Ultimate Sink: Urban Air, Land, and Water Pollution in Historical Perspective” Records of the Columbia Historical Society, Vol. 51, 1984, pp. 1-29.

[52] John A. Alic, "The Origin and Nature of the US 'Military-Industrial Complex'," Vulcan, Vol. 2, 2014, pp. 63-97.

[53] Polls have repeatedly found that Americans favor investments in energy conservation and renewables over coal and oil.www.gallup.com/poll/2167/energy.aspx. 